\title{
Analysis of the Utilization of VCO as a Glucose Level Reducing Material in Brown Rice Using a UV-VIS Spectrophotometer
}

\author{
Manik E. Magdalena and Herlinawati* \\ Department of Chemistry, Faculty of Mathematics and Sciences, Medan State University, Medan 20221, \\ Indonesia \\ *Email : herlinawati77@unimed.ac.id
}

\section{ABSTRACT}

This research aims to determine the effect of adding VCO on glucose levels in brown rice that cooked by rice cooker and steamer. Sample preparation is done by adding VCO to brown rice and cooking simultaneously. The samples were measured for their glucose levels by adding phenol and sulfuric acid to the sample and then measuring their absorbance using a UV-VIS spectrophotometer. The results showed that the addition of VCO affected glucose levels in brown rice. The highest level of glucose in brown rice was 32,178 ppm without the addition of VCO and the lowest level was $0.946 \mathrm{ppm}$ with the addition of 5\% VCO. Meanwhile, the highest level of glucose in brown rice in a steamer was 22,268 ppm without the addition of VCO and the lowest was 0,768 ppm with the addition of $5 \% \mathrm{VCO}$.

Keywords: Brown rice, VCO, glucose level, UV -VIS spectrophotometer

\section{Pendahuluan}

International Diabetes Federation (IDF) mengungkapkan bahwa pada tahun 2017 jumlah penderita DM di seluruh dunia mencapai 425 juta jiwa dan terus meningkat menjadi 463 juta jiwa pada tahun 2019. Jumlah penderita DM di Indonesia berdasarkan Top Ten Countries or teritories for number of adult with diabetes dengan jumlah 10,7 juta yang menempati peringkat ketujuh dunia. ${ }^{1} \quad$ Tingginya kadar glukosa darah merupakan masalah utama pada penderita diabetes mellitus. Oleh karena itu, perlu dilakukan penyeimbangan asupan makanan dengan ketersediaan insulin untuk mencapai dan mempertahankan kadar glukosa darah pada kisaran normal. Menurut Satria, berkurangnnya kadar karbohidrat dan glukosa pada makanan, akan menjadikan makanan menjadi lebih aman dikonsumsi, khususnya penderita diabetes mellitus. ${ }^{2}$ Dalam penelitian yang dilakukan oleh
Sofyan diperoleh hasil bahwa kadar glukosa pada nasi dari beras merah adalah 23,31 ppm dan kadar glukosa pada nasi dari beras putih adalah 29,54 ppm. ${ }^{3}$

Menurut Muchtadi, diabetes mellitus atau secara singkat disebut sebagai diabetes, adalah kondisi dimana seseorang mempunyai kadar gula darah (glukosa) melebihi kondisi normal, baik disebabkan karena tubuh tidak memproduksi insulin dalam jumlah yang cukup, atau karena sel sel tubuh tidak merespon secara baik tehadap insulin yang diproduksi. ${ }^{4}$ Menurut Siagian, jenis bahan makanan yang dianjurkan untuk penderita DM tipe 2 adalah makanan yang kaya serat dan karbohidrat kompleks, salah satu contohnya adalah pati resisten. ${ }^{5}$ Menurut Birt, pati resisten tipe 5 (RS5) terbentuk ketika pati berinteraksi dengan lipid, sehingga amilosa membentuk kompleks heliks tunggal dengan asam lemak dan lemak alkohol. Rantai linear pati dalam struktur heliks 
akan membentuk kompleks dengan asam lemak dalam rongga heliks, sehingga pati akan saling mengikat dan sulit dihidrolisis oleh enzim amilase. ${ }^{6}$

VCO (Virgin Coconut Oil) dapat digolongkan sebagai asam lemak jenuh (saturated). Sehingga penulis ingin melakukan penelitian dengan judul "Analisis Pemanfaatan VCO Sebagai Bahan Penurun Kadar Glukosa Pada Nasi Merah Menggunakan Spektrofotometer UV - VIS”

\section{Metodologi Penelitian}

\subsection{Alat dan Bahan}

Alat - alat yang akan digunakan dalam penelitian ini adalah spektrofotometer, neraca digital, alat sentrifugasi, magnet stirrer, peralatan gelas lainnya, lumpang dan alu, kertas saring, kukusan, dan rice cooker.

Bahan - bahan yang akan digunakan dalam penelitian ini adalah beras merah, buah kelapa, asam sulfat pekat (merck), fenol 5\%, glukosa dan aquades.

2.2. Prosedur penelitian

a. Pembuatan VCO

Daging kelapa di parut dan ditambahkan dengan air kemudian diperas. Kemudian santan yang diperoleh dimasukkan ke dalam corong pisah dan dibiarkan selama 3 jam. Santan akan terbagi menjadi 2 lapisan, yaitu krim dan skim. Lapisan bagian krim diambil dan di sentrifuge dengan kecepatan $1000 \mathrm{rpm}$ selama 90 menit. Setelah disentrifugasi terbentuk 3 lapisan yaitu lapisan minyak VCO, lapisan krim dan lapisan air. Lapisan minyak VCO diambil untuk kemudian digunakan pada prosedur selanjutnya.

b. Pembuatan Kurva kalibrasi Dan Penentuan Persamaan Garis Regresi Linear

Pembuatan kurva standar dilakukan dengan cara mengambil $2 \mathrm{~mL}$ larutan standar glukosa (10, 20, 30, 40, dan $50 \mathrm{ppm}$ ) dan memasukkannya dalam tabung reaksi, kemudian ditambahkan dengan $1 \mathrm{~mL}$ larutan fenol 5\% kemudian dikocok. Setelah itu ditambahkan $5 \mathrm{~mL}$ asam sulfat pekat dan larutan didiamkan selama 10 menit, lalu dikocok. Kemudian ditempatkan dalam penangas air selama 15 menit. Lalu ditempatkan dalam kuvet yang telah distandarisasi. Selanjutnya larutan tersebut diukur absorbansinya pada panjang gelombang maksimum dengan menggunakan spektrofotometer visible dan dibuat kurva kalibrasi. c. Penentuan Kadar Glukosa Pada Nasi Merah

Sebanyak 500 gram beras merah tanpa penambahan VCO dan dengan penambahan VCO 3\%, 4\% dan 5\% masing - masing dimasak dengan cara pemasakan yang berbeda, yaitu kukusan dan rice cooker. 10 gram nasi merah diambil, dihaluskan kemudian dimasukkan dalam gelas kimia $250 \mathrm{~mL}$, ditambahkan $100 \mathrm{~mL}$ aquades, diaduk selama 30 menit. Larutan yang dihasilkan disaring dan diambil filtratnya. Filtrat disentrifugasi selama 15 menit dengan kecepatan $3000 \mathrm{rpm}$. Filtrat hasil dekantasi dipipet sebanyak 1 $\mathrm{mL}$ lalu dimasukkan dalam labu ukur $250 \mathrm{~mL}$, ditambahkan aquades hingga tanda batas, dan dikocok selama 2 menit $^{8}$. Larutan diambil $2 \mathrm{~mL}$ kemudian dimasukkan kedalam tabung, ditambahkan dengan $1 \mathrm{~mL}$ larutan fenol 5\%, dan dikocok. Campuran tersebut ditambah $5 \mathrm{~mL}$ asam sulfat pekat, didiamkan selama 10 menit, dikocok, ditempatkan dalam penangas air selama 15 menit. Kemudian ditempatkan dalam kuvet yang telah distandarisasi. Diukur absorbannya dengan menggunakan spektrofotometer pada panjang gelombang $490 \mathrm{~nm}$. Kadar glukosa ditentukan dengan menggunakan persamaan regresi linear. Perlakuan ini dilakukan pada nasi merah yang dimasak dengan kukusan dan rice cooker

\section{Hasil dan Diskusi}

3.1. Kurva kalibrasi larutan standar glukosa dan persamaan garis regresi linear

Sebelum menganalisis kadar glukosa dalam sampel, terlebih dahulu dilakukan pengukuran larutan standar dengan beberapa konsentrasi untuk memperoleh kurva kalibrasi dengan konsentrasi larutan standar glukosa $(10,20,30,40,50)$ ppm. Kurva kalibrasi digunakan untuk menentukan konsentrasi analit dalam sampel $^{7}$. Konsentrasi analit dapat ditentukan dari persamaan garis regresi linear yang diperoleh. Kalibrasi dilakukan dengan cara mereaksikan larutan standar glukosa yang digunakan dengan fenol dan asam sulfat sehingga membentuk kompleks warna sehingga dapat dideteksi dengan spektrofotometri UV-VIS. Penambahan asam sulfat pekat akan menghasilkan senyawa hidroksi metal furfural berwarna oranye (Andaka, 2010). 


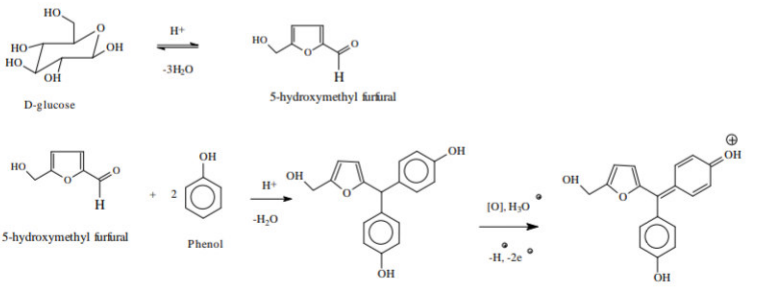

Gambar 1. Uji molish (Boahen, 2015)

Larutan ditempatkan dalam kuvet yang telah distandarisasi lalu diukur absorbansinya pada panjang gelombang maksimum, yaitu $484 \mathrm{~nm}$ dengan menggunakan spektrofotometer UV-Vis dan diperoleh data hasil pengukuran kurva kalibrasi larutan standar glukosa pada tabel 1.

Tabel 1. Data absorbansi larutan standar glukosa

\begin{tabular}{|c|c|}
\hline Konsentrasi (ppm) & Absorbansi (A) \\
\hline 10 & 0,609 \\
\hline 20 & 0,715 \\
\hline 30 & 0,832 \\
\hline 40 & 0,875 \\
\hline 50 & 1,088 \\
\hline
\end{tabular}

Berdasarkan data yang diperoleh pada tabel maka kurva kalibrasi larutan standar glukosa dapat dilihat pada gambar 1 .

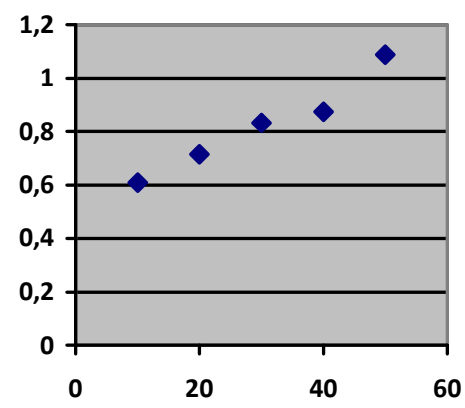

$\diamond \mathrm{XY}$ (Scatter) 1

Gambar 2. Kurva kalibrasi lautan standar glukosa.

Dari pengukuran diperoleh data kurva kalibrasi dengan persamaan regresi linear $\mathrm{y}=$ $0,0112 \mathrm{x}+0,4884$, dengan harga $\mathrm{R}^{2}=0,958$.

\subsection{Penentuan kadar glukosa pada nasi merah}

Sampel yang diperoleh dari beras merah dengan penambahan VCO sebanyak $0 \%, 3 \%, 4 \%$ dan $5 \%$ dimasak menggunakan rice cooker dan kukusan sampai menjadi nasi, diukur kadar glukosanya menggunakan instrumen
Spektrofotometer UV - VIS pada panjang gelombang $484 \mathrm{~nm}$.

Hasil pengukuran absorbansi dari sampel nasi merah dengan menggunakan spektrofotometer $\mathrm{UV}$ - Vis diperoleh data pada tabel 2.

Tabel 2. Data absorbansi larutan sampel

\begin{tabular}{|c|c|c|c|c|}
\hline \multirow{2}{*}{ Sampel } & \multicolumn{4}{|c|}{ VCO } \\
\cline { 2 - 5 } & $0 \%$ & $3 \%$ & $4 \%$ & $5 \%$ \\
\hline $\begin{array}{c}\text { Nasi merah } \\
\text { dalam rice } \\
\text { cooker }\end{array}$ & 0,128 & 0,238 & 0,556 & 0,499 \\
\hline $\begin{array}{c}\text { Nasi merah } \\
\text { dalam kukusan }\end{array}$ & 0,239 & 0,244 & 0,520 & 0,497 \\
\hline
\end{tabular}

Absorbansi sampel yang diperoleh dari hasil analisa pengukuran dengan menggunakan spektrofotometer UV - Vis di atas kemudian dimasukkan kedalam persamaan regresi linear $\mathrm{y}=$ $0,0112 \mathrm{x}+0,4884$, menjadi $\mathrm{A}=0,0112 \mathrm{x}+0,4884$ dan akan diperoleh $\mathrm{x}$ sebagai kadar glukosa pada nasi merah. Sehingga hasil perhitungan kadar glukosa pada nasi merah dapat dilihat pada tabel 3 .

Tabel 3. Data kadar glukosa pada nasi merah

\begin{tabular}{|c|c|c|c|c|}
\hline \multirow{2}{*}{ Sampel } & \multicolumn{4}{|c|}{ VCO } \\
\cline { 2 - 5 } & $0 \%$ & $3 \%$ & $4 \%$ & $5 \%$ \\
\hline $\begin{array}{c}\text { Nasi merah } \\
\text { dalam rice } \\
\text { cooker }\end{array}$ & 32,178 & 22,357 & 6,036 & 0,946 \\
\hline $\begin{array}{c}\text { Nasi merah } \\
\text { dalam kukusan }\end{array}$ & 22,268 & 21,821 & 2,821 & 0,768 \\
\hline
\end{tabular}

\section{Kesimpulan}

Kadar glukosa tertinggi pada nasi merah dalam rice cooker adalah 32,178 ppm tanpa penambahan VCO dan terendah adalah 0,946 ppm dengan penambahan VCO 5\%. Kadar glukosa tertinggi pada nasi merah dalam kukusan adalah 22,268 ppm tanpa penambahan VCO dan terendah adalah 0,768 ppm dengan penambahan VCO 5\% . Berdasarkan data diatas diketahui bahwa semakin tinggi persentasi penambahan VCO maka semakin rendah kadar glukosa yang terdapat pada nasi merah.

\section{Acknowledgement}

Ucapan terima kasih penulis ucapkan kepada Laboratorium Kimia Universitas Negeri Medan yang telah mengizinkan penulis melakukan penelitian. Penulis juga mengucapkan terimkasi 
kepada Ibu Dr. Herlinawati, M.Si yang telah banyak memberi masukan dan bimbingan kepada penulis selama melakukan penelitian. Terimaksikasih kepada orangtua penulis yang selalu memberikan doa, motivasi, nasehat, dukungan serta kasih sayang yang tidak terhingga yang diberikan kepada penulis dari mulai perkuliahan hingga menyelesaikan penelitian ini.

\section{Referensi}

1. Internasional Diabetes Federation. (2017). IDF Diabetes Atlas. Diakses pada tanggal 24 November 2017, dari https:// www. idf.org/ elibrary/epidemiology- research/diabetesatlas.html.

2. Satria, K., Rohmawati, N., Sulistiyani, S. (2018). Analisis Kandungan Karbohidrat, Glukosa, Dan Uji Daya Terima Pada Nasi Bakar, Nasi Panggang, Dan Nasi Biasa. Jurnal Agroteknologi, 12(1).

3. Sofyan. (2018). Perubahan kadar glukosa pada nasi beras merah dan nasi beras putih selama penyimpanan dalam pemanas. Skripsi,Universitas Tadulako, Palu.

4. Muchtadi, D. (2011). Karbohidrat Pangan Dan Kesehatan. Bandung : Alfabeta.

5. Siagan, R.A. (2014). Faktor-faktor yang mempengaruhi indeks glikemik pangan, indeks glikemik dan beban glikemik beberapa jenis pangan indeks glikemik pangan: Cara mudah memilih pangan yang menyehatkan. Jakarta : Swadaya

6. Birt,D.F., Boylston,T., Hendrich,S., Lane,J., Hollis,J., Whitley,M.P. (2013). Resistant Starch Promise for Improving Human Health. Advances in Nutrition. 4(6): 587-601.

7. Banjarnahor, L.R., Rahmah, S., Damanik, M., Zubir, M. (2020). Synthesis of Fe and $\mathrm{Zn}$ Organic Fertilizer From Palm Oil Waste. Indonesian Journal of Chemical Science and Technology. 3(2): 57-60.

8. Sofiyanita dan Nurhayati, S. (2018). Determining the Content of Nutrition and Organoleptic Test of Chips from Jackfruit Seed and Durian Seed. Indonesian Journal of Chemical Science and Technology. 1(1): 4349.

9. Agastya, G.A. (2016). Pengaruh Peningkatan Konsentrasi NaOH Pada Proses Delignifikasi Selulosa Mikrokristal (MCC) Dari Jerami Padi Beras Merah Lokal (Oryza sativa L. var Barak cenana). Skripsi, Universitas Udayana, Bali

10. Andaka, G. (2010). Hidrolisis Ampas Tebu Menjadi Furfural Dengan Katalisator Asam Sulfat. Jurnal Teknologi. 4(2) : 180-188.
11. Ardiansih, R. (2017). SPF Ekstrak Etanol Beras Merah. Skripsi, UMP, Bayumas.

12. Boahen, Y dan Isaac, A. (2015). Colorimetric Determination Of Charbohydrates In Some Brands Of Beer In Ghana As An Indication Of Their Glycemic Index In The Management Of Diabetes Type II. African Journal Of Food Science and Technology, 6(7): $2141-5455$. 